Vol.6 No.1 Tahun 2020
Jurnal Teknologi dan Manajemen Informatika
http:// http://jurnal.unmer.ac.id/index.php/jtmi
P-ISSN: 1693-6604 E-ISSN: 2580-8044

\title{
UTAUT Model Implementation on User Behavior in Use of Information Technology
}

\author{
Aan Nehru Awanto ${ }^{1}$, Yusaq Tomo Ardianto ${ }^{2}$, Dwi Arman Prasetya ${ }^{3}$ \\ ${ }^{1}$ Student of Magister Management, University of Merdeka Malang, East Java, Indonesia \\ ${ }^{2}$ Lecturer of Faculty Economy and Business, University of Merdeka Malang, East Java, \\ Indonesia \\ ${ }^{3}$ Lecturer of Faculty Engineering, University of Merdeka Malang, East Java, Indonesia
}

\begin{tabular}{|c|c|}
\hline Article Info & ABSTRACT \\
\hline Article Hictory & Purpose - analyze and retest the technology use and \\
\hline Diterima: 05-04-2020 & where there are four main variables that affect user intention \\
\hline Disetujui: $28-04-2020$ & and user behavior in using information technology. \\
\hline & $\begin{array}{l}\text { Methodology - this study uses a quantitative method, and } \\
\text { data obtained using questionnaires. Sampling uses survey }\end{array}$ \\
\hline$\underline{\text { Keywords }}$ & techniques with a total sample of 50 employees of the \\
\hline Performance Expectation; & Tourism and Culture Office of Malang Regency. The \\
\hline Effort Expectation; & essing data uses the SPSS \\
\hline Supporting Conditions; & program. \\
\hline $\begin{array}{l}\text { Behavioral Intention To Use; } \\
\text { User Behavior }\end{array}$ & $\begin{array}{l}\text { Research Findings - this study shows that in the technology } \\
\text { acceptance model, user intention and user behavior can be } \\
\text { influenced by four variables such as performance, effort, } \\
\text { social influence, and supporting conditions. }\end{array}$ \\
\hline
\end{tabular}

Corresponding Author

Yusaq Tomo Ardianto

Lecturer of Faculty Economy

and Business, University of

Merdeka Malang, East Java,

Indonesia

Tel. +6281803836606

yusaqtomo71@gmail.com

\section{INTRODUCTION}

Information technology provides many advantages to support the implementation of organizational tasks. According to Handayani (2010), the need for information technology has become a basic requirement for every organization, especially in carrying out its activities. This condition was driven by rapid technological development. Information technology is currently being developed marked by the number of companies or organizations that apply and use it for their activities. One of the factors to measure the success of information technology application is human resources because acceptance of system user can affect the achievement or disappointment of the application system. According to Jogiyanto (2008), behavioral aspects are human resource factors that can decide the acceptance or rejection of information technology applications. Previous studies have shown that the effect of successful technology 
implementation is more on its behavioral aspects. The many facilities that are facilitated by the development of information technology directly affect the activities of the organization.

Besides providing benefits, sometimes there are also organizations that fail to apply and use information technology. Davis (1989) said that several factors, both internal and external factors cause the failure to apply information technology systems in organizations. Many information technology systems fail because of the technical aspects, namely the poor technical quality of the system, also due to syntax errors, logical errors, and even incorrect information. The technical quality of information technology systems has undergone many improvements, but it cannot be avoided that here is also an information system that fails in its implementation (Jogiyanto, 2007). Jogiyanto (2007) also said that the cause of failure in the present period is more likely to be a behavioral aspect. System user behavior is formed from user attitudes and perceptions of information system applications.

Venkatesh et al. (2003) developed the Unified Theory of Acceptance and Use of Technology (UTAUT) which explains the user of acceptance of information technology, This model combines eight models of information technology usage that were successfully developed before. This model shows the performance expectation, the effort expectation, social influence, and supporting conditions influence the interest to use and the behavior to use technology. As a gender, age, experience, and the voluntaries of use moderate those four factors before. Venkatesh et al. (2003) states that there is a significant and positive relationship between performance expectation, the effort expectation, and social influence to the interest in using information technology and a significant and positive relationship between interest in using information technology and condition that help users to use information technology.

The Tourist and Culture Office of Malang Regency has used information technology in carrying out its duties, including the Regional Management Information System (SIMDA), Regional Goods Management Information System (SIMBADA), Personal Information System (SIMPEG), E-Budgeting and others. Until now it was felt that the utilization of information technology was still not optimal. This condition can be seen from the rarity of employees who access the system. Several researchers have adopted and use the UTAUT model to explain the organizational behavior (users) in using information technology and are expected to explain the user behavior in using information technology in the Tourist and Culture Office of Malang Regency

\section{Performance expectation with behavioral intention}

Performance expectation is the convictions of an individual in enhanching performance by way of using a system that helps their duties. Venkatesh et al. (2003) described the benefits of the system for its users with regard to usability, motivation, job-fit, and relative benefits. Continuous system use by users and the assumption ease get admission to information shows the level of interest of users in using information technology. Usability, motivation, and benefits acquired from the use of information technology will encourage users to use that information technology to improve their performance. Based on the description, the hypothesis is:

$H_{1}$ : there is a relationship between performance expectation and interest in using information technology (behavioral intention)

\section{Effort expectation with behavioral intention}

Effort expectation is conveniently obtained by the system users both energy and time to complete the work. Venkatesh et al. (2003) combined three variables found in the earlier model, such as perceived ease of use (TAM/Technology Acceptance Model), the complexity (Model of PC Utilization), and the ease of use (IDT/Innovation Diffusion Theory). The convenience obtained from the use of information technology will make users express their interest that the 
system has the ease and convenience of working with the system (Venkatesh and Davis, 2000). Based on the description, the hypothesis is:

$\mathrm{H}_{2}$ : there is a relationship between effort expectation and interest in using information technology (behavioral intention)

\section{Social influence with behavioral intention}

Social influence is defined as an outside influence or other people through the support of coworkers, superiors, and organizations in convincing a person to use a new system (Venkatesh et al., 2003). Support from other people to a system user will improve their performance in utilizing the system. This means that social factors have a positive effect on the use of information technology (Triandis, 1980 in Tjhai, 2003). Likewise, Venkatesh et al. (2003) which stated that there was a positive and significant relationship between social influence to the interest in using information technology, then the hypothesis is as follows:

$H_{3}$ : there is a relationship between social influence and interest in using information technology (behavioral intention)

\section{Supporting conditions with behavioral intention}

Supporting conditions are organizational support and technical support in the form of infrastructure that facilitates the usage of the system. The convenience will increase interest in the use of information technology and will produce usage behavior that can support performance to be better (Triandis, 1980). Conditions that help the usage of information technology are one of the factors that influence the usage of information technology (Schultz and Slevien, 1975). Yu-Lung Wu, Yu-Hui Tao, Pei-Chi Yang (2007), Sedana and Wijaya (2010), and Kristoforus and Andayani (2013) suggest that supporting conditions have a positive impact on interest in use. It can be said that conditions that help employees have an impact on the interest in using information technology. Based on the description above, the hypothesis is as follows:

$\mathrm{H}_{4}$ : there is a relationship between supporting conditions and interest in using information technology (behavioral intention)

\section{Behavioral intention with user behavior}

The behavior of using information technology is the intensity and or frequency of users in using information technology. Triandis (1980) suggested that the social factors, feelings, and perceived consequences affect a person's behavior in expressing their desires or interests. The behavior of using information technology is very dependent on the evaluation of users of the system, whether the systems get success or get failure. Thompson et al. (1991) stated that there was a positive relationship between interest in the use and the use of information technology. The interest in use will increase as each belief uses information technology in their work. Venkatesh et al. (2003) supported which stated that interest in the use of information technology has a direct and significant relationship to the use of information technology. So the hypothesis is:

$H_{5}:$ there is a relationship between behavioral intention and user behavior

$H_{6}$ : there is a relationship between performance expectation, effort expectation, social influence, supporting conditions, and interest in using information technology (behavioral intention)

\section{RESEARCH METHOD}

This study uses a quantitative method, data obtained using questionnaires and rating scale are arranged based on a Likert scale. The study population is 50 employees of the Tourist and Culture Office of Malang Regency who used information technology. Data were collected, 
tabulated, and analyzed using the SPSS program. This study uses the independent variable performance expectation (X1) with indicators of relative-advantage, perceivedusefulness, and outcome expectation. Effort expectation variable (X2) using indicators ease of use, and perceived ease of use. Social influence variable (X3) using indicators of subjective norms and social factors. Supporting conditions variable (X4) using perceived behavioral control and supporting conditions, while the dependent variable behavioral intention (Y1) using indicator of an intention to use, and use behavior variable (Y2) using indicator of the intensity of use, based on the Venkatesh et al. model (2003).

\section{RESULT AND DISCUSSION}

The test results show that the instruments used in this study are valid and reliable. The results of the validity test using SPSS show that each item variable in this study is valid, $r_{v a l u e}>r_{\text {table }}$ (0.275). The results of the reliability test indicate that the alpha reliability coefficient of each variable is greater than 0.60 , so the study analysis can be done.

Table 1. Results of Descriptive Analysis

\begin{tabular}{lc|lc}
\hline Performance expectation & Mean & Effort expectation & Mean \\
Perceived-Usefulness & 4,24 & Perceived Ease of Use & 3,99 \\
Relative-Advantage & 4,04 & Ease of Use & 3,90 \\
Outcome-Expectations & 4,05 & & \\
\hline Social influences & Mean & Supporting conditions & Mean \\
Subjective Norm & 4,26 & Perceived Behavioral Control & 3,93 \\
Social Factors & 4,5 & Supporting conditions & 3,79 \\
\hline Behavioral Intention & Mean & Use Behavior & Mean \\
Intention to Use & 4,03 & Intensity of Use & 4,05 \\
\hline
\end{tabular}

The indicators of the performance expectation show that the perceived usefulness has the highest mean value, this means that the use of the system will facilitate the work and make it possible to complete tasks faster. Indicators of effort expectation show the perceived ease of use has the highest mean value, which means employees feel easy in using and understanding information technology. Indicators of social influence indicate that social factors have the highest mean value which mean that organizational support in the use of information technology is very high. Indicators of supporting conditions indicate that behavior control has the highest mean value, meaning that respondents have adequate knowledge and resources in the use of information technology. The use behavior indicator shows that the frequency of employees in using information technology is influenced by the interest of employees in utilizing existing information technology. The following results show the test for causality analysis: 


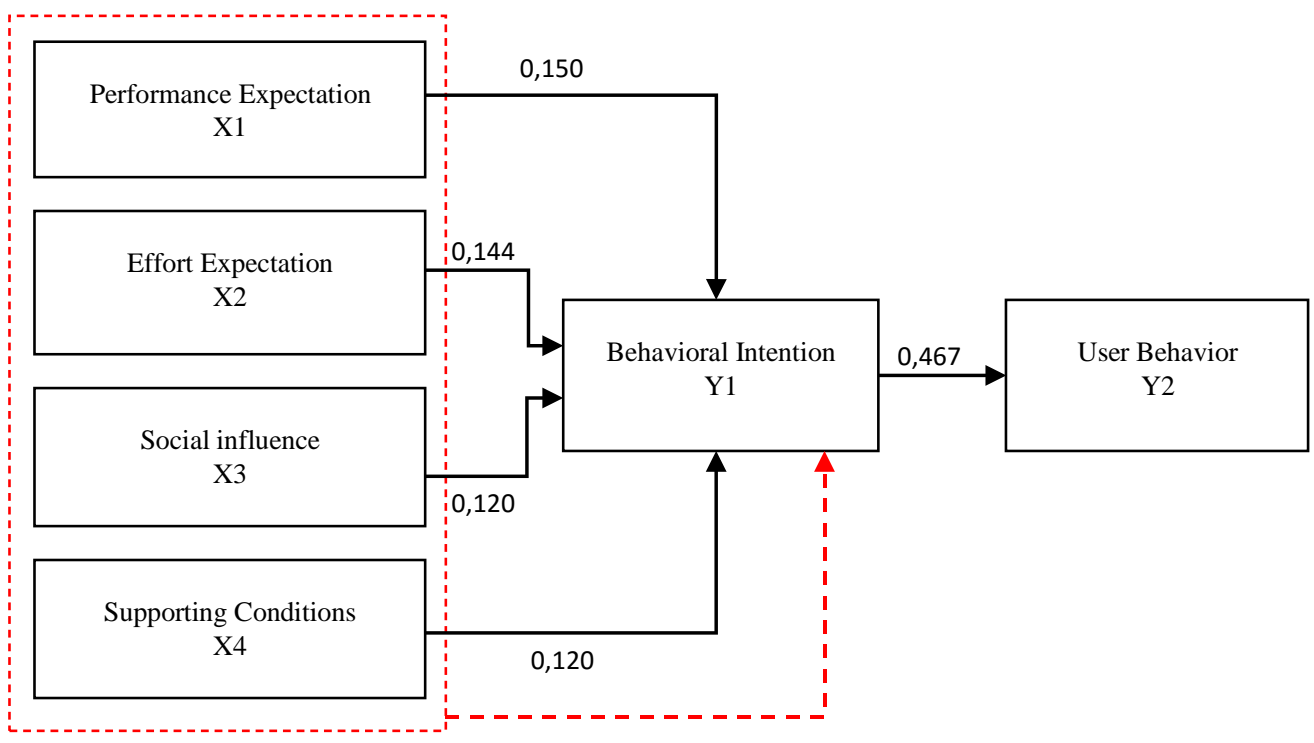

Figure 1. Result of Causality Analysis

The figure above shows that performance expectation, effort expectation, social influence, and supporting conditions affect the behavioral intention and user behavior in using information technology. The results also show that observation data are distributes normally with Sig. (0.375). The autocorrelation test results is 1.456 , so multicollinearity and heteroscedasticity do not occur in this study. The following table shows statistical results and hypothesis:

Table 2. Results of Hypothesis Test

\begin{tabular}{|c|c|c|c|c|c|c|c|}
\hline Variable & $\begin{array}{l}\text { Regression } \\
\text { Coef. }\end{array}$ & $\begin{array}{c}\text { Result tcount } \\
\text { Behavioral Intention }\end{array}$ & F count $C$ & \multicolumn{2}{|c|}{ FcountChronbach's VIF } & \multicolumn{2}{|c|}{ DW Hypothesis } \\
\hline Performance Expectation (X1) & 0.150 & 2.797 & 1.67962 .327 & 0.768 & 5.111 & 1.456 & Accepted \\
\hline Effort Expectation (X2) & 0.144 & 2.279 & & 0.781 & 2.002 & & Accepted \\
\hline Social Influence (X3) & 0.120 & 2.357 & & 0.794 & 3.348 & & Accepted \\
\hline Supporting Conditions (X4) & 0.120 & 2.231 & & 0.718 & 2.944 & & Accepted \\
\hline Behavioral Intention (Y1) & 0.467 & & & 0.759 & & & \\
\hline Varis & $\begin{array}{l}\text { Regression } \\
\text { Coef. }\end{array}$ & $\begin{array}{c}\text { Result } \text { tcount } \\
\text { Behavioral Intention }\end{array}$ & $F_{\text {count }} \mathrm{C}$ & $\begin{array}{l}\text { Tronbacl } \\
\text { Alpha }\end{array}$ & $\mathbf{I F}$ & DW & Results \\
\hline Behavioral Intention (Y1) & 0.467 & 6.481 & 1.67742 .000 & 0.759 & 1.00 & 01.817 & Accepted \\
\hline
\end{tabular}

User Behavior (Y2)

The table above shows the results of performance expectation variable obtained $t_{\text {count }}$ $(2.797)>t_{\text {table }}(1.679)$, and Sig. (0.008) < alpha (0.05), so the hypothesis is accepted. This shows that the performance expectation variable (X1) to behavioral intention (Y1) has a significant influence. The effort expectation variable obtained $t_{\text {count }}(2.279)>t_{\text {table }}(1.679)$ and Sig. (0.027) $<$ alpha (0.05), so the hypothesis is accepted. This shows that the effort expectation variable (X2) to behavioral intention (Y1) has a significant influence. The social influence variable obtained $t_{\text {count }}(2.357)>t_{\text {table }}(1.679)$, and Sig. $(0.023)<$ alpha $(0.05)$, so the hypothesis is accepted. This shows that the social influence variable (X3) to behavioral intention (Y1) has a significant influence. The supporting conditions variable obtained $t_{\text {count }}(2.231)>t_{\text {table }}(1.679)$, and Sig. $(0.031)<$ alpha $(0.05)$, so the hypothesis is accepted. This shows that the supporting conditions variable (X4) to behavioral intention (Y1) has a significant influence. The results of behavioral intention variable obtained $t_{\text {count }}(6.481)>t_{\text {table }}(1.677)$, and Sig. $(0.000)<$ alpha (0.05), so the hypothesis is accepted. This indicates that the variable behavioral intention (Y1) to use behavior (Y2) has a significant influence. 
The hypothesis test results prove that behavioral intention is significantly influenced by performance expectation. The indicators used are relative-advantage, perceived-usefulness, and outcome expectation. Most respondents think that utilizing information technology can offer a performance advantage in their work such as easier and faster, increasing productivity, and increasing effectiveness. This finding is by the results of Venkatesh et al. (2003) where performance expectation has a positive influence on the interest in using information technology (behavioral intention).

Indicators of effort expectation used in this study were ease of use and perceived ease of use. The hypothesis test results state that most of the respondents have the perception that it does not need hard effort in utilizing information technology because it is simple to understand, simple to master, and simple to use. This result is by the findings of Venkatesh and Davis (1996) and Venkatesh et al. (2003) which stated that the interest in using information technology (behavioral intention) influenced by effort expectation.

The results of the hypothesis test using social influence indicators of subjective norms and social factors obtained data showed the average respondent stated that the environment, organization, and leadership policies could affect the usage of information technology. This findings is the same as Triandis (1980) in Tjhai (2003), Venkatesh et al. (2003), and Handayani (2007) which stated that social influence variable has an influence on behavioral intention.

The condition that support directly influence the interest in using information technology. The respondents feel they have the resources and knowledge to use information technology, the adequate systems, and experts when obstacles, and the frequency of use of information technology are very high in completing work. So those supporting conditions resulted in greater interest in the use of information technology. This findings supports Schultz and Slevien (1975) who stated that one of the factors that influence the use of information technology is supporting conditions, as well as Y.L. Wu, Y.H. Tao, and P.C. Yang (2007), Sedana and Wijaya (2010), Kristoforus and Andayani (2013) suggested that supporting conditions to behavioral intention has a positive influence.

The results also show that behavioral intention has a direct positive influence on the use of behavior of information technology. Based on these results it can be interpreted that the higher the interest in using information technology, the higher the use of information technology by employees so that the results of the work obtained will be more ideal. This finding is similar to Thompson et al. (1991), and Venkatesh et al. (2003) were both stated that behavioral intention has a positive relationship with the user behavior of information technology.

The four variables such as performance expectation, effort expectation, social influence, and supporting conditions together can increase behavioral intention, and among the four independent variables, the performance expectation variable is the most dominant. This proves that the expected performance gains from the use of information technology in completing work, productivity, effectiveness, and efficiency are very stron. This finding is like Sedana and Wijaya (2010), Kristoforus and Andayani (2013) which stated that four variables above have a significant influence on behavioral intention.

\section{CONCLUSION}

According to the mean values of descriptive analysis of each variable, this study shows that the average respondent agrees to the variable such as performance expectation, effort expectation, social influence, supporting condition, behavioral intention, and user behavior, and all variables are proper to analyze. Based on the results of the analysis, performance expectation, effort expectation, social influence, and supporting conditions has a significant influence on behavioral intention to use, so the hypothesis concludes that there are joint (simultaneous) influences of the four independent variables to behavioral intention variable are acceptable. The results of other analysis show that behavioral intention has a significant influence to user 
behavior so it can be concluded that there is an effect of variables of interest in the use of actual usage behavior can be accepted. Among the four independent variables in this study, the performance expectation variable is the most dominant variable. The results of the F-test and ttest are used to find the effect of each independent variables and dependent variables. Based on the test results obtained all independent variables have a significant influence on interest in use (behavioral intention) and behavioral intention influence user behavior. This study still has limitation, therefore it still requires improvement in the next study. From the analysis results obtained by R-square (0.847), which means that the four independent variables influence the $84.7 \%$ of variables of behavioral intention, while $15.3 \%$ are other variables that have not been studied, such as gender, age, experience, and the voluntaries of use. Addition of other variables or indicators might be needed to enrich the model in the next study.

\section{REFERENCES}

[1] Davis, F.D. (1989). Perceived Usefulness, Perceived Ease of Use, and User Acceptance of Information Technology. MIS Quarterly 13(3), page 319-340.

[2] Handayani, R. (2007). Analisis Fakor-Faktor yang Mempengaruhi Minat Pemanfaatan Sistem Informasi dan Pengunaan Sistem Informasi (Studi Empiris pada Perusahaan Manufaktur yang Terdaftar di Bursa Efek Jakarta). Journal Universitas Kristen Petra.

[3] Handayani, R. (2010). Analisis Pengaruh Komputer Anxiety dan Self Efficacy terhadap Keahlian Penggunaan Internet pada Mahasiswa. Riset Manajemen dan Akutansi, Volume 1 Nomor 2 Edisi November 2010.

[4] Jogiyanto, H. M. (2007). Sistem Informasi Keperilakuan. Yogyakarta: Andi Offset.

[5] Jogiyanto, H. M. (2008). Metodologi Penelitian Sistem Informasi. Yogyakarta: Andi Offset.

[6] Kristoforus. R. and S. Andayani (2013). Analisis Perilaku Pengguna Sistem Informasi Menggunakan Model UTAUT. Semarang: Seminar Nasional Teknologi Informasi \& Komunikasi Terapan.

[7] Nyoman Sedana, I Gusti and Wisnu, St Wijaya. (2010). UTAUT Model for Understanding Learning Management System. Internetworking Indonesia Journal Vol. 2 No. 2.

[8] Schultz, E.M., and Slevien D.P. (1975). Implementation and Organizational Validity: An Empirical Investigation. In Implementing Operation Research/Management Science. New York, pp. 163-182.

[9] Thompson, R. Higgins, C. Howell, J. (1991). Personal Computing: Toward a Conceptual Model of Utilization. MIS Quarterly. March, Vol. 15 No. 1, pp. 124-143.

[10] Tjhai, Fung Jing. (2003). Analisis Faktor-Faktor yang Mempengaruhi Pemanfaatan Teknologi Informasi terhadap Kinerja Akuntan Publik. Jurnal Bisnis dan Akuntansi. 5(1):1-26.

[11] Triandis, H.C. (1980). Values, Attitudes, and Interpersonal Behavior, in Howe, H. E. (ed) Nebraska Symposium on Motivation, 1979: Beliefs, Attitudes, and Values.

[12] Venkatesh, V. and Davis, F.D. (1996). A Model of Antecedents of Perceived Ease of Use: Development and Test. Decision Sciences, 27(3) 451-481.

[13] Venkatesh, V. (2000). Determinants of Perceived Ease of Use: Integrating Control, Intrinsic Motivation, and Emotion into the Technology Acceptance Model. Information System Research, 11(4), page 342-365.

[14] Venkatesh, V., Morris, M.G., Davis, G.B., and Davis, F.D. (2003). User Acceptance of Information Technology: Toward a Unified View: MIS Quarterly, 27(3), page 425-478.

[15] Yu-Lung Wu, Yu-Hui Tao, Pei-Chi Yang. (2007). Using UTAUT to Explore the Behavior of $3 \mathrm{G}$ Mobile Communication Users. IEEE International Conference on

Industrial Engineering and Engineering Management, page 199-203 